\title{
SELF-AWARENESS PADA KELUARGA RESIKO TINGGI DIABETES MELLITUS DI TAMPAT DURIAN KURANJI : STUDI KASUS
}

\author{
Leni Rozani ${ }^{1}$, Hema Malini ${ }^{2}$, Leni Merdawati ${ }^{3}$ \\ 1,2,3 Program Studi S2 Keperawatan, Kekhususan Kepemimpinan dan Manajemen Keperawatan, Fakultas \\ Keperawatan, Universitas Andalas, Padang \\ E-mail : bunda4isya@gmail.com
}

\begin{abstract}
Type 2 Diabetes Mellitus disease is a disease with the greatest number of sufferers of all kinds of Diabetes Mellitus. Diabetes Mellitus disease can be prevented by modifying lifestyle. This study explores self-awareness of a group of high risk of Diabetes Mellitus. This case study uses descriptive qualitative research methods. Data were obtained by interviewing three participants who were at high risk and had family histories suffer from Diabetes Mellitus. The results of the interviews were analyzed using the Corbin and Strauss method where there were three stages of analysis, open coding, axial coding and selective coding. The results showed, a pattern that similar to all participants which is knowledge, attitudes and behaviors of Diabetes Mellitus that were not good in the community. The result reviewed using Johari Window theory. The lack of self-awareness of high risk Diabetes Mellitus community is because they are individuals who are in the hidden area. This individuals are difficult to care, share, open or accept the opinions of others. They solve problems based on their own thoughts and desires, therefore only themselves know about their health problems.
\end{abstract}

Keywords : Diabetes Mellitus type 2, High risk of Diabetes Mellitus, Self-Awareness, Risk Factors, Case Study

\begin{abstract}
Abstrak : Penyakit Diabetes Mellitus tipe 2 merupakan penyakit dengan jumlah penderita terbayak dari semua Diabetes Mellitus. Penyakit Diabetes Mellitus tipe 2 ini dapat dicegah dengan melakukan modifikasi gaya dan pola hidup. Penelitian ini bertujuan mengeksplorasi self-awareness kelompok resiko tinggi Diabetes Mellitus. Penelitian ini menggunakan metode penelitian kualitatif deskriptif dengan pendekatan studi kasus. Data didapatkan dengan mewawancarai tiga orang partisipan yang beresiko tinggi dan mempunyai riwayat keluarga dengan penyakit Diabetes Mellitus. Hasil wawancara dianalisis dengan menggunakan metode Corbin dan Strauss dimana analisis ini ada tiga tahap yaitu open coding, axial coding dan selective coding. Hasil penelitian menunjukkan, terdapat sebuah pola yang sama dari semua partisipan resiko tinggi yaitu kurangnya pengetahuan, sikap dan perilaku pencegahan Diabetes Mellitus yang belum baik dimasyarakat. Kurangnya self-awareness masyarakat resiko tinggi Diabetes Mellitus disebabkan oleh partisipan resiko tinggi merupakan individu-individu dengan hidden area. Individu-individu ini sulit untuk peduli, berbagi, terbuka atau menerima masukan orang lain. Mereka menyelesaikan masalah berdasarkan pemikiran dan sesuai kehendaknya sendiri, oleh karenanya hanya diri mereka sendiri yang mengetahui masalah kesehatannya.
\end{abstract}

Kata kunci : Diabetes Mellitus tipe-2, Resiko tinggi Diabetes Mellitus, Self-Awareness

\section{PENDAHULUAN}

Diabetes Mellitus adalah masalah kesehatan global yang tumbuh paling serius dan mengancam, menyebabkan morbiditas dan mortalitas dini. Diabetes Mellitus adalah salah satu dari empat penyakit tidak menular yang menyebabkan 50 juta kematian setiap tahun. Diabetes Mellitus tipe-2 menyebabkan $90-95 \%$ dari semua kasus diabetes diseluruh dunia (ADA, 2017).

Di Asia, Indonesia adalah penderita Diabetes nomor tiga terbesar setelah Cina dan India dan peringkat ketujuh di dunia (WHO, 2016). Berdasarkan data dari Kementerian Kesehatan Indonesia 2014, hanya $30,4 \%$ penderita Diabetes didiagnosis, $69,6 \%$ tidak terdiagnosis
(Pusdatin Kemenkes RI, 2014). Faktanya satu dari dua orang dewasa atau $46 \%$ dari 415 juta orang yang hidup dengan Diabetes tidak menyadari bahwa mereka menderita Diabetes (Perkeni, 2015).

Di Kota Padang, Sumatra Barat (Dinkes Padang, 2016), dari 2015 hingga 2016 pasien Diabetes Mellitus meningkat dari 18.456 menjadi 22.529 orang. Kasus baru ditemukan sebanyak 4.073 orang diindikasikan sebagai penderita Diabetes Mellitus dari total populasi penduduk Padang yang berjumlah 914.968 orang,dimana $\pm 2,47 \%$ dari penduduk yang ada di Kota Padang sudah terjangkit penyakit Diabetes Mellitus (BPS Kota Padang, 2016). Dinkes Padang mencatat 
jumlah penderita Diabetes Mellitus di Kuranji berjumlah 1.581 orang.

Tahapan Diabetes Mellitus tipe-2 yang lambat, sering membuat gejala dan tandatanda keluhan pada umumnya hampir tidak diperhatikan oleh pasien (Betteng, 2014). Diagnosis penderita Diabetes tipe 2 sering tertunda, sehingga sebagian besar penderita tahu menderita Diabetes setelah komplikasi (Garber et al., 2017). Kondisi paling umum yang terkait dengan Diabetes Mellitus termasuk kematian tinggi, morbiditas, penurunan kualitas hidup dan biaya sosial ekonomi yang tinggi (Wilkinson et al., 2014).

Diabetes Mellitus berdampak pada kualitas sumber daya manusia dan peningkatan substansial dalam biaya kesehatan.Sangatlah penting untuk memiliki program kontrol Diabetes Mellitus Tipe-2 yang bertugas langsung kelapangan memantau masyarakat yang beresiko tinggi terhadap Diabetes Mellitus. Diabetes Melitus tipe-2 dapat dicegah, ditunda dengan mengendalikan faktor-faktor risiko (Trisnawati \& Setyorogo, 2013). Kesadaran diri dalam pengendalian glikemik dapat membantu seseorang mempertahankan status kesehatannya. Kesadaran diri ini dapat timbul dari adanya pengetahuan yang cukup, dan akan terus berlanjut sebagai kehendak kuat yang diterapkan pada perubahan perilaku penderita Diabetes menjadi perilaku sehat (Sari, 2016). Pengetahuan dan kesadaran diri akan membuat perbedaan yang luar biasa dalam kontrol glikemik (Khan et al., 2015). Individu dengan kesadaran diri kurang, 20 kali berisiko lebih tinggi untuk komplikasi dari pada individu dengan kesadaran diri yang baik (Yanti, 2009).

Berdasarkan survei yang telah dilakukan, peneliti menemukan keluarga besar penderita Diabetes Mellitus. Keluarga ini mengalami kematian tinggi dan beruntun disebabkan penyakit Diabetes Mellitus dan komplikasinya. Kelompok keluarga ekonomi menengah ke atas ini, memiliki pendidikan tinggi, dan dapat dengan mudah mengakses informasi dan layanan kesehatan. Keluarga ini sadar akan potensi risiko yang mereka hadapi tetapi, masih sangat minim kesadaran diri untuk melakukan upaya pencegahan, pengendalian komplikasi Diabetes Mellitus.

\section{METODE PENELITIAN}

Desain penelitian ini adalah penelitian kualitatif deskriptif dengan pendekatan studi kasus untuk mengeksplorasi self-awareness kelompok berisiko tinggi Diabetes Mellitus di Tampat Durian Kuranji, Kota Padang. Penelitian dilakukan dengan membuat pohon keluarga dari keluarga besar penderita penyakit Diabetes. Partisipan dipilih berdasarkan purposive sampling yaitu sampel penelitian dipilih berdasarkan kriteria yang telah diterapkan oleh Peneliti. Peneliti menetapkan sembilan kriteria, jika tujuh atau lebih kriteria terpenuhi maka calon Partisipan akan dijadikan partisipan penelitian. Setelah dilakukan pengelompokan, peneliti mendapatkan tiga orang partisipan yang memenuhi kriteria.

Pengambilan data selama wawancara dilakukan oleh peneliti sendiri sebagai pemandu wawancara. Instrumen yang digunakan dalam penelitian adalah pedoman wawancara, catatan lapangan, alat perekam suara, timbangan berat badan dan meteran untuk melihat berat badan normal, serta tensi meter untuk melihat tekanan darah partisipan.

Tabel 1. Gambaran Karakteristik Partisipan

\begin{tabular}{ccc}
\hline $\begin{array}{c}\text { Partisipan 1 } \\
\text { (P1) }\end{array}$ & $\begin{array}{c}\text { Partisipan 2 } \\
\text { (P2) }\end{array}$ & $\begin{array}{c}\text { Partisipan 3 } \\
\text { (P3) }\end{array}$ \\
\hline Perempuan & Laki-laki & Perempuan \\
33 Tahun & 23 Tahun & 38 Tahun \\
Menikah & Belum menikah & Menikah \\
\hline Berat Badan & Berat Badan & Berat Badan \\
Single 42kg & SMA70-80kg & Single 40kg \\
Terukur 65kg & Terukur 115kg & Terukur 70kg \\
\hline Tinggi150cm & Tinggi 170cm & Tinggi 142cm \\
\hline
\end{tabular}




\begin{tabular}{|c|c|c|}
\hline $\begin{array}{c}\text { Tekanan Darah } \\
110 / 90 \mathrm{mmHg} \\
\end{array}$ & $\begin{array}{l}\text { Tekanan Darah } \\
140 / 100 \mathrm{mmHg}\end{array}$ & $\begin{array}{l}\text { Tekanan Darah } \\
140 / 110 \mathrm{mmHg}\end{array}$ \\
\hline Diploma 3 & Mahasiswa & SMA \\
\hline Pegawai & Belum bekerja & Berjualan \\
\hline $\begin{array}{l}\text { Pendapatan } \\
\text { Suami istri } \\
\pm \text { Rp. 5juta/bln }\end{array}$ & $\begin{array}{l}\text { Pendapatan } \\
\text { Dari orang tua } \\
\text { Rp.1.8juta/bln }\end{array}$ & $\begin{array}{l}\text { Pendapatan } \\
\text { Suami istri } \\
\text { Rp.2-3juta/bln }\end{array}$ \\
\hline $\begin{array}{c}\text { Diabetes pada } \\
\text { lbu }\end{array}$ & $\begin{array}{c}\text { Diabetes pada } \\
\text { Ayah }\end{array}$ & $\begin{array}{c}\text { Diabetes pada } \\
\text { lbu }\end{array}$ \\
\hline $\begin{array}{c}\text { Keluhan } \\
\text { Hypertiroid } \\
\text { Sakit kepala } \\
\end{array}$ & $\begin{array}{l}\text { Keluhan } \\
\text { Pusing }\end{array}$ & $\begin{array}{c}\text { Keluhan } \\
\text { Kepala berat } \\
\text { Leher kaku }\end{array}$ \\
\hline BPJS & BPJS/Umum & Umum \\
\hline
\end{tabular}

\section{HASIL PENELITIAN}

Tabel 2. Apa Saja yang Saudara Ketahui tentang Penyakit Diabetes Mellitus?

\begin{tabular}{|c|c|c|}
\hline & Kata Kata Partisipan & Properties \\
\hline Pengetahuan & $\begin{array}{l}\text { P1. Kelebihan gula dalam darah sehingga untuk proses kerja } \\
\text { darah ke insulin. } \\
\text { P2. Kemampuan tubuh tidak bisa lagi menyeimbangi kadar gula } \\
\text { darah. } \\
\text { P3. Tidak mengerti definisi Diabetes Mellitus. }\end{array}$ & $\begin{array}{l}\text { Definisi Diabetes } \\
\text { Mellitus sebagian } \\
\text { sudah } \\
\text { mengetahui }\end{array}$ \\
\hline Jenis/Tipe & $\begin{array}{l}\text { P1. Diabetes Mellitus } 1 \text { jenis. } \\
\text { Banyak orang mengatakan gula basah, gula kering. } \\
\text { P2. Jenis Diabetes Mellitus ada 2,Gula kering, gula basah. } \\
\text { P3. Banyak jenis Diabetes Mellitus, ada yang disuntik sebelum } \\
\text { makan ada yang tidak, Diabetes Mellitus jenis kering dan } \\
\text { basah. }\end{array}$ & $\begin{array}{l}\text { Masih belum } \\
\text { mengetahui Jenis } \\
\text { Diabetes Mellitus } \\
\text { (masih menurut } \\
\text { masyarakat } \\
\text { awam) }\end{array}$ \\
\hline $\begin{array}{c}\text { Tanda dan } \\
\text { Gejala }\end{array}$ & $\begin{array}{l}\text { P1. Lelah, Berkeringat } \\
\text { Sering Buang air kecil } \\
\text { P2. Badan semakin lama semakin kurus, Nafsu makan meningkat, } \\
\text { Pusing, Lelah. } \\
\text { P3. Lelahan, Letih, Sering buang air kecil, Mata mengantuk. }\end{array}$ & $\begin{array}{l}\text { Mengetahui } \\
\text { sebagian kecil } \\
\text { tanda dan gejala } \\
\text { Diabetes Mellitus }\end{array}$ \\
\hline $\begin{array}{c}\text { Faktor } \\
\text { Penyebab }\end{array}$ & $\begin{array}{l}\text { P1. Keturunan. } \\
\text { Makan banyak, imbangi dengan olah raga dan aktifitas fisik lain. } \\
\text { P2. Keturunan. } \\
\text { P3. Keturunan }\end{array}$ & $\begin{array}{l}\text { Mengetahui } \\
\text { sebagian kecil } \\
\text { faktor penyebab } \\
\text { Diabetes Mellitus }\end{array}$ \\
\hline $\begin{array}{l}\text { Persepsi } \\
\text { tentang } \\
\text { Diabetes } \\
\text { Mellitus }\end{array}$ & $\begin{array}{l}\text { P1. Tidak bisa disembuhkan namun dapat dikontrol. } \\
\text { P2. Kalau sudah kena seperti papi, tidak bias sembuh lagi } \\
\text { P3. Diabetes Mellitus bisa disembuhkan dengan rutin minum obat } \\
\text { dan makan menurut takaran yang sesuai. } \\
\text { Diabetes Mellitus tidak bisa sembuh total. Diabetes Mellitus bisa } \\
\text { kambuh. }\end{array}$ & $\begin{array}{l}\text { Persepsi tentang } \\
\text { Diabetes Mellitus } \\
\text { masih ada yang } \\
\text { salah }\end{array}$ \\
\hline $\begin{array}{l}\text { Jenis diet } \\
\text { dan aktifitas } \\
\text { fisik }\end{array}$ & $\begin{array}{l}\text { P1. Makanan dan minuman: Nasi, lauk, sayur, buah. Buah yang } \\
\text { dimakan pisang, jeruk, nanas, papaya, papaya pun cuma } \\
\text { sesekali, beli lauk, kalau pulang kerja rasanya capek, } \\
\text { makanan selain nasi diiselingi bakso, pangsit, miso kadang } \\
\text { sate, mie, Sekarang tidak minum kaleng lagi, cuma air putih } \\
\text { saja. Paling minuman kayak seperti teh }{ }^{\star} \text { cuk, fr*sti, tidak ada } \\
\text { minuman yang bergas gitu, dalam memasak menggunakan } \\
\text { penyedap masakan, tidak merokok dan minum alkohol" } \\
\text { Aktifitas fisik: Kalau olah raga memang kurang boleh dibilang } \\
\text { tidak ada, kegiatan dirumah, menyapu sekeliling rumah lalu } \\
\text { ngurus anak cuma itu saja. } \\
\text { P2. Makanan dan minuman: Nasi, lauk, sayur, buah. Nasi sehari, } \\
\text { Kira kira } 2 \text { piring sekali makan, menyukai gorengan, mie }\end{array}$ & $\begin{array}{l}\text { Makanan banyak } \\
\text { mengandung } \\
\text { karbohidrat, } \\
\text { menyukai } \\
\text { makanan dan } \\
\text { minuman instan, } \\
\text { kurang buah dan } \\
\text { serat, } \\
\text { menggunakan } \\
\text { penyedap } \\
\text { Frekuensi dan } \\
\text { waktu makan }\end{array}$ \\
\hline
\end{tabular}




\section{Kata Kata Partisipan}

instan, nasi goreng, lauk pauk digoreng saja, makan buah jarang, kadang malas beli buah, sayur Ada, tapi kurang suka,

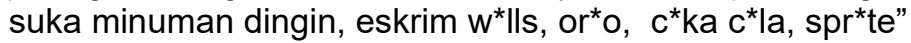

Aktifitas fisik: Tidak ada, kegiatan sehari hari ke kampus, kalau di rumah tidur, menonton, main laptop, itu saja, karena malas, tidak ada teman juga.

P3. Makanan dan minuman: Nasi, lauk, Lontong, Sate, sesekali Roti, Bakso, kadang kadang selagi menggoreng pisang atau bakwan, sambil dimakan juga,sayur dan buah, teh dan kopi memasak sayur menggunakan penyedap.

Aktifitas fisik: Mana sempat olahraga, sibuk keluar masuk bikin kopi, teh ke dapur, bikin ketupat, mencuci piring itu saja. Aktifitas sambilduduk memotong bawang, sayur, bikin ketupat, istirahat Kadang ada, kadang tidak, kadang tiduran di kursi tertidur sebentar Cuma itu, kalau benar istirahat tidak ada, kecuali kalau lagi demam, kecapean, kalau tidak ya tidak ada. Kalau jualan ini sampai jam 10/11 sampai orang habis sepi.

P1. Makanan dan minuman: Nasi 3 kali sehari Kadang kurang dari sepiring, mungkin karna sering ngemil atau karena pikiran senang, bisa jadi jugakan?

Sayur sedikit, Buah jarang karna tidak suka.

Aktifitas fisik: Jarang sekali olah raga, kecapean kerja, jadi jarang olahraga, mungkin karena olahraganya gitu aja

P2. Makanan dan minuman: Nasi 6 piring sehari gorengan 10 buah 3 kali seminggu, kadang kalau lagi duduk di warung

$\begin{array}{cc}\text { Jumlah/ } & \text { gorengannya enak di beli, kalau tidak ya tidak } \\ \text { Frekuensi } & \text { Makan buah jarang, kadang malas beli buah }\end{array}$

Sayur Ada, tapi kurang suka, seminggu kadang ga ada

Aktifitas fisik: Senam tidak ada, jarang sekali

P3. Makanan dan minuman: Nasi 2kali sehari

Sayur dan buah Jarang, bisa dikatakan tidak Ada, hanya kalau pengen saja

Kalau minuman kaleng jarang, teh dan kopi pun jarang bikin sendiri paling kalau uda yang bikin, ikut minum seteguk, sudah

Aktifitas fisik: Tidak ada olahraga

P1. Makan nasi pagi, siang, malam. Kalau ada waktu, masak, kalau pulang kerja rasanya capek, beli lauk saja

P2. Makan tidak jelas waktunya

Ngemil diantara jam makan kalau tidak sedang lapar sekali

Waktu Minuman kalau lagi pengen, kepanasan, lagi punya uang

Kadang kalau lagi duduk di warung gorengannya enak di beli, kalau tidak ya tidak

P3. Nasi pagi dan siang, sayur dan buah hanya kalau pengen saja

Teh dan kopi kalau uda yang bikin, ikut minum seteguk, sudah.

Tabel 3. Bagaimana Perasaan Saudara Mempunyai Keluarga Penderita Diabetes Mellitus.

\begin{tabular}{|c|c|c|}
\hline Perasaan & Kata kata partisipan & Properties \\
\hline $\begin{array}{l}\text { Perasaan } \\
\text { terhadap } \\
\text { kondisi } \\
\text { Diabetes } \\
\text { Mellitus }\end{array}$ & $\begin{array}{l}\text { P1. Rasanya cemas, diaberes dapat diturunkan, sedih melihat orang } \\
\text { tua menderita Diabetes Mellitus." } \\
\text { P2. Perasaan takut Diabetes Mellitus diturunkan keanak. Tidak ingin } \\
\text { juga sakit gula karena sangat tergantung obat, sedih melihat } \\
\text { orang tua sakit, tidak mau seperti orang tua dan ingin orang tua } \\
\text { sembuh } \\
\text { P3. Kadang sedih juga melihat amak begitu, dulu badannya gemuk } \\
\text { sekarang kurus. }\end{array}$ & $\begin{array}{l}\text { Perasaan cemas, } \\
\text { takut dan sedih } \\
\text { terkait kondisi diri } \\
\text { dan keluarga } \\
\text { Upaya melakukan } \\
\text { perawatan } \\
\text { keluarga }\end{array}$ \\
\hline
\end{tabular}

Properties

tidak teratur, Aktifitas fisik sangat kurang 


\begin{tabular}{|c|c|c|}
\hline $\begin{array}{l}\text { Usaha } \\
\text { yang } \\
\text { dilakukan }\end{array}$ & $\begin{array}{l}\text { P1. Menjaga agar makan tidak banyak, menyuruh ama ke } \\
\text { Pukesmas } \\
\text { P2. Kalau untuk diri sendiri belum ada, sekarang bisa kasih tau } \\
\text { mami supaya rajin bawa papi berobat jangan sampai papi } \\
\text { kehabisan obat Diabetes Mellitusnya } \\
\text { P3. Jangan banyak tidur, untuk amak saya bilang, saya tidak mau } \\
\text { menunggui kalau dirawat dirumah sakit kalau amak tidak mau } \\
\text { menjaga makan }\end{array}$ & \\
\hline \multicolumn{2}{|c|}{ Kata kata partisipan } & \\
\hline \multicolumn{2}{|c|}{$\begin{array}{l}\text { P1. Tidak ada anjuran bidan dan teman untuk tes darah saat melahirkan anak } 4,2 \\
\text { kg. } \\
\text { P2. Sebenarnya takut jarum, melihat jarum agak merinding rasanya. } \\
\text { P3. Badan sehat sehat saja begini, apanya yang mau diperiksa. Kalau sudah sakit } \\
\text { baru diperiksa. Sekarang terserah bagaimana jadinya, kalau sakit baru } \\
\text { dipikirkan }\end{array}$} & $\begin{array}{l}\text { Keterbatasan } \\
\text { pengetahuan } \\
\text { dan persepsi } \\
\text { yang salah }\end{array}$ \\
\hline
\end{tabular}

Tabel 5.Tindakan yang Dilakukan untuk Pencegahan Diabetes Mellitus

\section{Kata kata partisipan}

P1. Tidak makan malam sudah dilakukan, jarang sekali olah raga capek sama kerjaan

P2. Diet, mengatur pola hidup, tidak begadang, olah raga teratur, tapi belum terlaksana baru sebatas niat

P3. Tidak tidur sesudah makan kalau olah raga tidak ada dilaksanakan paling bolak balik ngambilkan pelanggan makan

\section{Properties}

Sikap

pencegahan

Diabetes

Mellitus baru

sebatas niat

Tabel 6. Bentuk Dukungan Sosial dari Keluarga, Masyarakat dan Yankes

\begin{tabular}{|c|c|c|}
\hline Dukungan & Kata kata partisipan & Properties \\
\hline $\begin{array}{l}\text { Dukungan } \\
\text { keluarga }\end{array}$ & $\begin{array}{l}\text { P1. Suami menyuruh menurunkan berat badan } \\
\text { P2. Mami dan kakak menyuruh menurunkan berat badan, olah raga, } \\
\text { cek darah,kurangi makan. } \\
\text { P3. Larangan tidur sesudah makan oleh suami }\end{array}$ & \multirow{3}{*}{$\begin{array}{l}\text { Teridentifikasi } \\
\text { potensi dan } \\
\text { hambatan } \\
\text { mendapatkan } \\
\text { dukungan } \\
\text { keluarga dan } \\
\text { sosial }\end{array}$} \\
\hline $\begin{array}{l}\text { Dukungan } \\
\text { keluarga } \\
\text { dan } \\
\text { masyaraka } \\
\text { t }\end{array}$ & $\begin{array}{l}\text { P1. (Orangtua P1) Hubungan dengan orang tua tidak terlalu dekat } \\
\text { dan tidak berinteraksi dengan masyarakat sekitar. } \\
\text { P2. (Sepupu P2) P2 tidak berinteraksi dengan tetangga waktunya } \\
\text { dirumah dihabiskan untuk main game dan nonton didalam } \\
\text { kamar sambil tiduran, kurang dekat dengan saudara dan ada } \\
\text { masalah komunikai dengan orang tua masalah kuliah tak } \\
\text { kunjung selesai. } \\
\text { P3. (Adik P3) Hubungan dengan orang lain bagus tapi hubungan } \\
\text { dengan saudara dan orang tua berjalan seadanya atau kurang } \\
\text { dekat }\end{array}$ & \\
\hline $\begin{array}{l}\text { Dukungan } \\
\text { Yankes }\end{array}$ & $\begin{array}{l}\text { P1. Berobat pakai kartu BPJS, penyuluhan ada karumah tapi amak } \\
\text { yang sakit Diabetes Mellitus ja yang mendengarkan } \\
\text { P2. Kartu BPJS ada tapi tidak pernah digunakan, tidak ada } \\
\text { memeriksakan gula darah apalagi ke puskesmas kecuali waktu } \\
\text { mintak rujukan papi untuk rawat rumah sakit }\end{array}$ & \\
\hline
\end{tabular}

Tabel 7.Axial Coding dan Selective Coding berdasarkan Open Coding.

\begin{tabular}{lllll}
\hline \multicolumn{1}{c}{ Properties } & Open Coding & & Axial Coding & $\begin{array}{c}\text { Selective } \\
\text { Coding }\end{array}$ \\
\hline $\begin{array}{lllll}\text { Definisi Diabetes Mellitus sebagian } \\
\text { sudah mengetahui }\end{array}$ & $\begin{array}{l}\text { Pengetahuan } \\
\text { Belum mengetahui Jenis Diabetes }\end{array}$ & Diabetes Maksimal terutama tentang & Pengetahuan & Kurangnya \\
Mellitus (masih menurut masyarakat) & jenis Diabetes Mellitus, tanda & dengan & Diabetes & n, sikap dan \\
perilaku
\end{tabular}




\begin{tabular}{|c|c|c|c|}
\hline $\begin{array}{l}\text { Mengetahui sebagian kecil tanda dan } \\
\text { gejala Diabetes Mellitus }\end{array}$ & \multirow{5}{*}{$\begin{array}{l}\text { dan gejala, faktor resiko, pola } \\
\text { hidup sehat yaitu Pengelolaan } \\
\text { diet yang kurang baik dan } \\
\text { aktifitas fisik yang kurang }\end{array}$} & \multirow{10}{*}{$\begin{array}{l}\text { Mellitus dan } \\
\text { upaya } \\
\text { pencegahan } \\
\text { masih kurang. } \\
\text { Sikap dalam } \\
\text { pencegahan } \\
\text { Diabetes } \\
\text { Mellitus yang } \\
\text { belum } \\
\text { maksimal. }\end{array}$} & \multirow{10}{*}{$\begin{array}{l}\text { pencegahan } \\
\text { Diabetes } \\
\text { Mellitus } \\
\text { yang belum } \\
\text { baik }\end{array}$} \\
\hline $\begin{array}{l}\text { Mengetahui sebagian kecil faktor } \\
\text { penyebab Diabetes Mellitus }\end{array}$ & & & \\
\hline $\begin{array}{l}\text { Persepsi tentang Diabetes Mellitus } \\
\text { masih ada yang salah }\end{array}$ & & & \\
\hline $\begin{array}{l}\text { Makan banyak karbohidrat, menyukai } \\
\text { makanan dan minuman instan, } \\
\text { kurang buah dan serat, memakai } \\
\text { penyedap }\end{array}$ & & & \\
\hline $\begin{array}{l}\text { Frekuensi dan waktu makan tidak } \\
\text { teratur, Aktifitas fisik sangat kurang }\end{array}$ & & & \\
\hline $\begin{array}{l}\text { Perasaan cemas, takut dan sedih } \\
\text { terkait kondisi diri dan keluarga }\end{array}$ & $\begin{array}{l}\text { Kegelisahan diri dan upaya } \\
\text { perawatan keluarga }\end{array}$ & & \\
\hline $\begin{array}{lll}\text { Upaya } & \text { melakukan } & \text { perawatan } \\
\text { keluarga } & & \\
\end{array}$ & & & \\
\hline $\begin{array}{l}\text { Keterbatasan pengetahuan dan } \\
\text { persepsi yang salah }\end{array}$ & $\begin{array}{l}\text { Keterbatasan informasi terkait } \\
\text { pemeriksaan kesehatan. }\end{array}$ & & \\
\hline $\begin{array}{l}\text { Sikap pencegahan Diabetes Mellitus } \\
\text { baru sebatas niat }\end{array}$ & $\begin{array}{l}\text { Belum terlaksananya tindakan } \\
\text { pencegahan Diabetes Mellitus }\end{array}$ & & \\
\hline $\begin{array}{l}\text { Teridentifikasi potensi dan hambatan } \\
\text { mendapatkan dukungan sosial }\end{array}$ & $\begin{array}{l}\text { Fasilitas dan dukungan belum } \\
\text { dimanfaatkan secara } \\
\text { maksimal }\end{array}$ & & \\
\hline
\end{tabular}

\section{PEMBAHASAN}

Penelitian ini adalah penelitian pertama yang turun langsung kekeluarga besar penderita Diabetes Mellitus. Keluarga ini mengalami kematian tinggi dan beruntun disebabkan oleh penyakit Diabetes mellitus dan komplikasinya. Penelitian ini menggunakan pohon keluarga empat generasi, sampai generasi terakhir saat penelitian ini dilakukan. Peneliti memilih partisipan yang sangat beresiko terkena Diabetes Melitus diantara yang beresiko lainnya. Penelitian studi kasus ini menemukan bahwa ketiga partisipan penelitian menunjukkan pola yang sama dan menghasilkan satu selective coding yaitu kurangnya pengetahuan, sikap dan perilaku pencegahan Diabetes Mellitus yang belum baik. Selective coding ini berasal dari 3 axial coding diantaranya:

\section{Pengetahuan terkait Diabetes Mellitus dan upaya pencegahan masih kurang optimal}

Dalam penelitian ini peneliti menemukan Self awereness masyarakat resiko tinggi yang kurang akan kebutuhan mendapatkan pengetahuan dan keinginan yang rendah untuk menggali pengetahuan tentang penyakit Diabetes Mellitus serta penanganannya meski mereka memiliki pendidikan tinggi, tinggal di kota, akses informasi mudah didapatkan, layanan kesehatan tersebar di segala penjuru dan terlahir dari keluarga penderita Diabetes namun pengetahuan mereka sama dengan masyarakat pada umumnya yaitu merupakan kesimpulan mereka sendiri yang didapatkan dari pengalaman merawat keluarga maupun informasi lingkungan masyarakat yang juga minim pengetahuan tentang Diabetes Melitus. Hal ini tampak pada ungkapan P1"Jenis Diabetes Mellitus menurut saya cuma satu saja, kelebihan gula darah, tapi banyak juga orang yang mengatakan Diabetes Mellitus ada dua, gula kering dan gula basah". Demikian juga pada ungkapan P3 "Banyak jenis Diabetes Mellitus, ada yang disuntik sebelum makan ada yang tidak, Diabetes Mellitus jenis kering dan basah, kalau gula kering langsung habis, merosot berat badan, tenaga tidak ada lagi seperti orang tua saya. Orang tua saya badannya gemuk, segemuk saya badannya dulu".

Partisipan hanya mengetahui sebagian kecil tanda dan gejala Diabetes Mellitus seperti pernyataan P2 "Kalau saya tengok dari papi, badan makin lama makin kurus, nafsu makan tinggi, sering lelah dan pusing". P3 menyatakan "Kata orang yang sudah kena Diabetes Mellitus, buang air kecil katanya sering, mata ngantuk".

Pengetahuan masyarakat resiko tinggi tentang pola diet rendah. Mereka masih mengkonsumsi karbohidrat berlebihan, 
kurang serat dan sayur, menyukai minum manis dan bersoda serta menggunakan penyedap makanan. Seperti pernyataan P2 "Nasi sehari, Kira kira dua piring sekali makan, boleh dibilang sekali nambah, ikan goreng bercabe, lauk pauk goreng kadang makan gorengan juga, makan snack, gorengan 10 buah, dalam seminggu ada tiga kali kadang lebih makan gorengan, kadang kalau lagi duduk di warung gorengannya enak dibeli, kalau tidak ya tidak, kadang mie kadang nasi goreng, makan buah jarang, kadang malas beli buah, sayur ada, tapi kurang suka, minuman dingin es krim, minuman besoda, suka kalau lagi pengen, lagi kepanasan". Penelitian ini didukung oleh Masfufah et al, (2015) yang menyatakan, berdasarkan pengetahuan kadar glukosa darah menunjukkan bahwa responden yang memiliki pengetahuan kurang, terdapat Masyarakat resiko tinggi memiliki motivasi yang rendah dan prinsip yang salah terhadap pemeriksaan kesehatan. Akibatnya mereka belum melakukan pemeriksan dini terkait penyakit Diabetes Mellitus. Dari kondisi ini dapat dipastikan masyarakat resiko tinggi tidak mengetahui keadaan gula darahnya. Jika kondisi ini berlanjut maka, saat masyarakat mengetahui mengidap penyakit Diabetes Mellitus, mereka sudah disertai komplikasinya. Pernyataan berikut ini menggambarkan kondisi tersebut, P1 "Tidak adanya anjuran bidan saat melahirkan bayi besar, P2 "Takut akan jarum suntik", P3 "Kondisinya sehat saja sehingga tidak perlu diperiksa, kalau sudah sakit baru periksa". Sebagaimana penelitian Jomin et al (2015) setengah dari penderita Diabetes Mellitus tidak tahu bahwa mereka memiliki penyakit Diabetes Mellitus.

Mereka semua merasa cemas dan takut pada penyakit Diabetes Mellitus yang akan menimpa mereka dikemudian hari. Mereka juga prihatin dengan penyakit Diabetes Mellitus yang diderita keluarganya. Seperti P1 yang merasa cemas Diabetes Mellitus "kata orang" diturunkan, P2 yang juga menyatakan takut Diabetes Mellitus diturunkan ke anak, tidak ingin kena Diabetes Mellitus dan tergantung dengan obat seperti orang tuanya. Meski demikian, rasa cemas, takut, prihatin ini, tidak menumbuhkan self-awareness pada mereka. glukosa darah tidak terkontrol. Meskipun partisipan mengalami, melihat, mendengar tentang penyakit Diabetes namun tidak merubah sikap dan gaya hidup mereka.

\section{Sikap dalam Pencegahan Diabetes yang Belum Optimal}

Mengingat kematian yang beruntun akibat dari penyakit Diabetes Mellitus ini, bila tidak ada penanganan yang serius dan tepat, hanya mengandalkan pengalaman merawat keluarga dengan Dibetes Mellitus secara turun temurun, sumber informasi yang didapat tidak akurat maka, sikap dan perilaku masyarakat resiko tinggi akan terus mengarah pada percepatan timbulnya penyakit Diabetes Mellitus sehingga siklus/rantai kematian akibat Diabetes akan terus berlanjut dalam keluarga besar penderita Diabetes Mellitus ini.

\section{Kurang Memanfaatkan Fasilitas Yankes dan Dukungan Sosial}

Meski partisipan sadar dengan adanya Puskesmas, memiliki kartu BPJS, serta adanya dukungan keluarga. Partisipan tidak memanfaatkan dan mengabaikan dukungan yang ada untuk melakukan pemeriksaan terkait Diabetes Mellitus. P1 menyatakan "Anjuran suami menurunkan berat badan dan memeriksakan gula darah tapi malas saja untuk periksa", P2 "Anjuran dari orang tua untuk mengurangi makan dan melakukan pemeriksaan gula darah, mengurangi berat badan, orang tua sudah sakit tentu tidak ingin anaknya juga sakit", P3 "Anjuran dari suami seperti jangan banyak tidur dan periksa gula darah". Namun, peneliti menemukan dukungan keluarga hanya sebatas anjuran saja, keluarga belum proaktif dalam memberikan motivasi, dukungan dan dorongan seperti tidak mencarikan informasi yang akurat, tidak menemani langsung kepelayanan kesehatan untuk pemeriksaan serta, tidak ikut menerapkan pola hidup sehat,tidak ikut berolahraga dan terlibat langsung mengatur pola diet masyarakat resiko tinggi Diabetes Mellitus. Rondhianto, (2013) menyebutkan peran aktif keluarga dalam memberikan dukungan perlu ditingkatkan karena keluarga memerankan peran yang sangat penting dalam memberikan dukungan pada anggota keluarganya yang menghadapi stresor kehidupan. 


\section{KESIMPULAN DAN SARAN}

Berdasarkan penelitian studi kasus ini, peneliti menyimpulkan bahwa partisipan resiko tinggi merupakan individu individu dengan hidden area. Masyarakat ini sulit untuk berbagi, terbuka atau menerima masukan orang lain. Mereka menyelesaikan masalah berdasarkan pemikiran dan sesuai kehendaknya sendiri, oleh karenanya hanya diri mereka yang mengetahui masalah

\section{DAFTAR PUSTAKA}

ADA. (2017). Standards of Medical Care in Diabetes-2017, 40(January).

Betteng. (2014). Analis Faktor Resiko Penyebab Terjadinya Diabetes Mellitus Tipe2 pada Wanita Produktif Dipuskesmas Wawonasa. Jurnal eBiomedik (eBM), Volume 2, 9.

BPS Kota Padang. (2016). Badan Pusat Statistik Kota Padang. Retrieved November 13, 2017, from https://padangkota.bps.go.id/linkTable Dinamis/view/id/130

Dinkes Padang. (2016). Data diabetes Kota Padang tahun 2016. kota padang.

Garber, A. J., Abrahamson, M. J., Barzilay, J. I., Blonde, L., Bloomgarden, Z. T., Bush, M. A., Dagogo-Jack, S., et al. (2017). Consensus Statement By The American Association Of Clinical Endocrinologists And American College Of Endocrinology On The Comprehensive Type 2 Diabetes Management Algorithm - 2017 Executive Summary. Endocrine Practice.

Jomin, G., Sridevi, G., \& Pearson, C. (2015). Knowledge and awareness of diabetes mellitus: A Case Study of a large private University in Botswana. Statewide Agricultural Land Use Baseline 2015, 1(4), 50-55.

Khan, N. A., Venkatachalam, V. V, Al Akhali, K. M., Alavudeen, S. S., Dhanapal, C. K., Ansari, A., Mohammad, S., et al. (2015). Overview of Glycemic Control, Knowledge, Awareness and Attitude Among Type-2 Diabetes Male Patient'S. Noohu at el.. Journal of Applied Pharmacy, 7(1), 7582. Retrieved from www.japharmacy.ca

Masfufah, Hadju, V., \& Jafar, N. (2015). Pengetahuan, Kadar Glukosa Darah kesehatannya. Program selanjutnya dapat ditujukan untuk meningkatkan konseling berkala berupa komunikasi terapeutik pada masyarakat resiko tinggi sehingga terbina hubungan saling percaya dan diharapkan menimbulkan self-awareness untuk melakukan pencegahan terhadap Diabetes Mellitus. Situasi ini perlu ditindaklanjuti dengan program berkelanjutan dalam mengembangkan upaya pencegahan di masyarakat resiko tinggi.

dan Kualitas Hidup Penderita Diabetes Mellitus Tipe 2 Rawat Jalan di Wilayah Kerja Puskesmas Kota Makassar. Universitas Hasanuddin, 1, 1-12. Retrieved from http://repository.unhas.ac.id/bitstream/ handle/123456789/11329/MASFUFAH K21110284.pdf?sequence $=1$

Perkeni. (2015). Konsensus Pengelolaan dan pencegahan diabetes melitus tipe 2 di indonesia 2015. Pengurus Besar Perkumpulan Endokrinologi Indonesia (PB Perkeni).

Pusdatin Kemenkes RI. (2014). Situasi Dan Analisis Diabetes.

Rondhianto. (2013). Faktor yang berhubungan dengan hambatan diet Diabetes Mellitus pada pasien Diabetes Mellitus tipe 2 di wilayah kerja Puskesmas Wonosari kabupaten Bondowoso. Jurnal IKESMA, 9(1), 917.

Sari, N. P. W. P. (2016). Diabetes mellitus: hubungan antara pengetahuan sensoris, kesadaran diri, tindakan perawatan diri dan kualitas hidup, 4(1).

Trisnawati, S. K., \& Setyorogo, S. (2013). Faktor Risiko Kejadian Diabetes Melitus Tipe II Di Puskesmas Kecamatan Cengkareng Jakarta Barat Tahun 2012. Jurnal IImiah Kesehatan, 5(1), 6-11.

WHO. (2016). Global Report on Diabetes. Isbn, 978, 88. Retrieved from http://www.who.int/about/licensing/\%5 Cnhttp://apps.who.int/iris/bitstream/106 65/204871/1/9789241565257_eng.pdf

Wilkinson, A., Whitehead, L., \& Ritchie, L. (2014). Factors influencing the ability to self-manage diabetes for adults living with type 1 or 2 diabetes. International Journal of Nursing Studies, 51(1), 111-122. Elsevier Ltd. 
82 | Jurnal Kesehatan Mesencephalon, Vol.5 No.2, Oktober 2019, hlm 74-82

Retrieved from http://dx.doi.org/10.1016/j.jinurstu.2013 .01 .006

Yanti, S. (2009). Analisis Hubungan Kesadaran Diri Pasien dengan Komplikasi Diabetes Mellitus dalam Konteks Asuhan Keperawatan di RSUD Dr. Adnand W.D Payakumbuah. Universitas Indinesia. 